\title{
STATE OF HEALTH AND PHYSICAL FITNESS OF CBF (BRAZILIAN SOCCER CONFEDERATION) REFEREES FROM THE STATE OF ESPÍRITO SANTO
}

NoXERCIC10\%

Original Article ARTIGo ORIGINAL Artículo Original

ESTADO DE SAÚDE E APTIDÃO FÍSICA DE ÁRBITROS DE FUTEBOL DO ESTADO DO ESPÍRITO SANTO

DOQUADRODACBF

\author{
ESTADO DE SALUD Y APTITUD FÍSICA DE ÁRBITROS DE FÚTBOL DEL ESTADO DEL ESPÍRITO SANTO \\ DEL CUADRO DE LA CBF
}

\author{
Vitor Loureiro da Silva \\ (Physical Education Professional) \\ Carlos Eduardo do Rosário \\ Depizzol $^{2}$ \\ (Physical Education Professional) \\ Luciana Carletti \\ (Physical Education Professional) \\ Rodrigo Luiz Vancini² \\ (Physical Education Professional) \\ Ana Paula Lima Leopoldo² \\ (Physical Education Professional) \\ André Soares Leopoldo² \\ (Physical Education Professional)
}

1. Universidade Estadual Paulista (UNESP), Faculdade de Medicina, Department of Clinical Medicine, Botucatu, SP, Brazil.

2. Universidade Federal do Espírito Santo, Center of Physical Education and Sports, Department of Sports, Vitória, ES, Brazil.

\section{Correspondence}

André Soares Leopoldo.

Department of Sports, Center of

Physical Education and Sports,

UFES - Universidade Federal do

Espírito Santo, Vitória, ES, Brazil.

29075-910.

andre.leopoldo@ufes.br

\begin{abstract}
Introduction: Studies indicate that the technical/tactical performance of soccer referees can be impacted by physical fitness and state of health. However, although they are routinely invited to take part in matches at national level, it is not yet clearly established whether referees who work in less prominent regions and soccer championships present the same levels of physical, technical and psychological preparation as referees from more important areas, such as the soccer teams of São Paulo and Rio de Janeiro. Within this context, no studies have evaluated the physical conditioning and health parameters of Brazilian Soccer Confederation (CBF) referees who work in Espírito Santo. Objective: To assess the health and physical fitness levels of CBF soccer referees from Espírito Santo. Methods: A cross-sectional study with 16 participants, 6 referees, and 10 assistant referees. The protocol lasted 12 weeks and consisted of the following analyses: general characteristics, body composition, flexibility, and biochemical and cardiorespiratory profiles. Results: The referees all fell under the age range (26 to 41 years) required by CBF and had good body composition and flexibility results. The cardiorespiratory assessment (rest and effort) of the referees indicated satisfactory physical fitness and consequently, low risk for cardiovascular diseases based on resting heart rate (HR) (64 $\pm 13 \mathrm{bpm})$, HR reserve (126 $\pm 18 \mathrm{bpm})$ and $\mathrm{VO}_{2} \max \left(45.3 \pm 5.7 \mathrm{ml} \cdot \mathrm{kg}^{-1} \cdot \mathrm{min}^{-1}\right)$, results similar to those seen in elite international referees. Regarding the biochemical assessment, the parameters analyzed were within the normal range. Conclusion: Despite the fact that referees from the state of Espírito Santo work in a region of lesser national significance and relevance in the soccer domain, they present satisfactory levels of physical fitness and health parameters to act with safety and precision in national competitions. Level of Evidence IV; Type of study: Case series.
\end{abstract}

Keywords: Soccer referees; Effort test; Physical fitness; Health.

\section{RESUMO}

Introdução: Estudos apontam que o desempenho técnico/tático de árbitros de futebol de campo pode ser impactado pela aptidão física eestado de saúde. Contudo, embora sejam rotineiramente convocados parajogos em âmbito nacional, ainda não estábem estabelecido se os árbitros que atuam em regiões e campeonatos de futebol menos expressivos apresentam os mesmos níveis de preparação física, técnica e psicológica que os árbitros de centros de maior relevância, como o futebol paulista e carioca. Diante desse contexto, não foram encontrados estudos que avaliaram o condicionamento físico e os parâmetros de saúde de árbitros da Confederação Brasileira de Futebol (CBF) que atuam no Espírito Santo. Objetivo: Analisar a saúde e os níveis de aptidão física de árbitros de futebol do Espírito Santo. Métodos: Estudo transversal com 16 participantes, sendo 6 árbitros principais e 10 assistentes. O protocolo perdurou por 12 semanas efoi composto pelas seguintes análises: características gerais, composição corporal, flexibilidade eperfis bioquímico e cardiorrespiratório. Resultados: 0 grupo de árbitros apresentava idade dentro do limite máximo (26 a 41 anos) exigido pelo quadro da CBF e bons resultados de composição corporal eflexibilidade. A avaliação cardiorrespiratória (repouso eesforço) dos árbitros denotou aptidão física satisfatória e, consequentemente, baixo risco de doenças cardiovasculares a partir da frequência cardíaca (FC) de repouso $(64 \pm 13 \mathrm{bpm}), F C$ de reserva $(126 \pm 18 \mathrm{bpm})$ e VO $\mathrm{I}_{2}$ máx $\left(45,3 \pm 5,7 \mathrm{ml}^{\mathrm{kg}} \mathrm{kg}^{-1} \cdot \mathrm{min}^{-1}\right)$, resultados similares aos observados em árbitros de elite mundial. Quanto à avaliação bioquímica, os parâmetros analisados estavam dentro da normalidade. Conclusão: Os árbitros capixabas, mesmo atuando em uma região de menor expressão nacional e relevância no âmbito futebolístico, apresentam aptidão física e parâmetros de saúde satisfatórios para atuarem com segurança e precisão nas competições nacionais. Nível de Evidência IV; Série de casos.

Descritores: Árbitros de futebol; Testes Físicos; Aptidão física; Saúde.

\section{RESUMEN}

Introducción: Estudios apuntan que el desempeño técnico/táctico de árbitros de fútbol de campo puede ser impactado por aptitud física y estado de salud. Sin embargo, aunque sean rutinariamente convocados para partidos en el ámbito nacional, aún no está bien establecido si los árbitros que actúan en regiones y campeonatos de fútbol menos expresivos presentan los mismos niveles de preparación física, 
técnica y psicológica que los árbitros de centros de mayor relevancia, como el fútbol de São Paulo y del Rio de Janeiro. En este contexto, no hay estudios que evaluaron el condicionamiento físico y los parámetros de salud de árbitros de La Confederación Brasileña de Fútbol (CBF) que actúan en el Estado del Espirito Santo. Objetivo: Analizar la saludy los niveles de aptitud física de árbitros de fútbol del Espirito Santo que forman parte del cuadro de la CBF. Métodos: Estudio transversal con 16 participantes, siendo 6 árbitros principales y 10 asistentes. El protocolo perduró por 12 semanas y se compuso de los siguientes análisis: características generales, composición corporal, flexibilidad y perfiles bioquímico y cardiorrespiratorio. Resultados: El grupo de árbitros tenía edad dentro del límite máximo (26 a 41 años) exigido por el cuadro de la CBF y buenos resultados de composición corporal y flexibilidad. La evaluación cardiorrespiratoria (reposo y esfuerzo) de los árbitros denotó aptitud física satisfactoria y, consecuentemente, bajo riesgo de enfermedades cardiovasculares a partir de la frecuencia cardíaca (FC) de reposo (64 $\pm 13 \mathrm{bpm}), F C$ de reserva $(126 \pm 18 \mathrm{bpm}) \mathrm{VO}_{2}$ máx $\left(45,3 \pm 5,7 \mathrm{ml} \cdot \mathrm{kg}^{-1} \cdot \mathrm{min}^{-1}\right)$, resultados similares a los observados en árbitros de elite mundial. En cuanto la evaluación bioquímica, los parámetros analizados estaban dentro de la normalidad. Conclusión: Los árbitros del Espírito Santo, incluso actuando en una región de menor expresión nacional y relevancia en el ámbito futbolístico, presentan aptitud física y parámetros de salud satisfactorios para actuar con seguridad y precisión en competiciones nacionales. Nivel de evidencia IV; Serie de casos.

Descriptores: Árbitros De Fútbol; Pruebas Físicas; Aptitud física; Salud.

\section{INTRODUCTION}

Soccer - the most popular sport in Brazil and worldwide ${ }^{1}$ - has extraordinary media appeal. Thus, it is increasingly important that nothing gets in the way of the spectacle sold to fans of the sport. In this context, soccer referees, who can make errors noticeable by spectators, players, and coaching staff, frequently appear in controversies about the final match results.

Although soccer referees do not have a professional category and proper working conditions, they are required to perform intensive physical preparation to improve the quality of their refereeing. ${ }^{2}$ Soccer is a dynamic collective sport and has become a faster and more intense activity in recent years; this has led to more wear and tear and a greater demand for better physical and psychological conditions in the involved professionals. ${ }^{3}$ The literature shows that during a soccer match, the referees engage in predominantly aerobic activities of mild to moderate intensity, ${ }^{4}$ with a caloric expenditure between 494 and $740 \mathrm{kcal} .{ }^{5}$ In addition, referees need to cover large distances, which require high aerobic demand and the ability to perform repeated sprints. ${ }^{6}$ In the Spanish National Division, referees generally cover approximately $10 \mathrm{~km}(\approx 2.7 \mathrm{~km}$ at high speeds of $>18 \mathrm{~km} / \mathrm{h}$ ) and perform $21.3-30.5$ sprints at speeds of $>25.2 \mathrm{~km} / \mathrm{h}$. ${ }^{6.7}$

Given the importance of physical performance and the technical and tactical abilities of soccer referees, scientific research has been performed on the physiological demands related to these factors. ${ }^{8}$ D'Ottavio and Castagna ${ }^{9}$ evaluated the cardiovascular stress of Italian high-level referees, and showed that their heart rate (HR) reached 89.1\% of the estimated maximum over a complete match with no difference between the 1 st and 2 nd half. Krustrup and Bangsbo, ${ }^{10}$ examining the physiological demands of Danish referees, found that the HR and mean blood lactate concentration were $162 \pm 2$ beats per minute (bpm) $(85 \pm$ $1 \%$ of the maximum $\mathrm{HR}$ ) and $4.9 \pm 0.3 \mathrm{mmol} / \mathrm{L}$, respectively. Krustrup et al. ${ }^{11}$ showed that the mean HR was $137 \mathrm{bpm}$ (73\% of the maximum HR and $65 \%$ of the maximum oxygen consumption $\left[\mathrm{VO}_{2}\right.$ max]) in assistant referees and observed that the blood lactate concentration was 4.7 and $4.8 \mathrm{mmol} / \mathrm{L}$ after the $1 \mathrm{st}$ and 2 nd half, respectively.

It is important to point out that monitoring of the physical conditioning of international referees and assistants has been carried out using the structured test battery implemented in 2001 by the Fédération Internationale de Football Association (FIFA). ${ }^{2}$

In general, seasonal tests show that soccer referees are well conditioned, have good physical fitness, and have a low risk of developing chronic diseases. ${ }^{2,12} \mathrm{An}$ important aspect is that a higher $\mathrm{VO}_{2}$ max and a lower body fat percentage, which are fundamental indices of the physical condition, have been related to the good technical/tactical performance of referees during soccer matches. ${ }^{3}$ In addition, when aerobically well-conditioned, referees maintain optimum speed peaks for a longer time and have better positioning in the field during the match, shortening the distances for identifying fouls. This scenario allows the referees to make precise and convincing decisions. ${ }^{4}$ Mazaheri et al. ${ }^{13}$ pointed out that an elite soccer referee is exposed to physical demands similar to those of a midfield player, whose predominant action is to run long distances during the match.

In Brazil, few studies have investigated the physical fitness of soccer referees and aspects related to their health.,12,14-16 Specifically in Espírito Santo, a state with leagues and clubs of lower tier and relevance in the national scenario, there are no studies addressing this issue. It is important to emphasize that optimizing physical fitness, in addition to reducing the risk of cardiac events in referees may be important for their decision making during a match, helping them avoid mistaking player postures because of their own physical exhaustion, which may influence the final outcome of the match., Within this context, when assigned to national-level matches, these referees with less work requirement, as a consequence of working in lower-level clubs and leagues, must be prepared to meet the physical demands. However, the professional assistance provided to referees outside the Rio-São Paulo-Minas Gerais-Rio Grande do Sul axis is precarious. Thus, the objective of this study was to evaluate the health and physical fitness parameters of Brazilian Football Confederation (CBF) referees working in the state of Espírito Santo (capixabas referees).

\section{METHODS}

\section{Study design}

The study was performed over a period of 12 weeks, beginning with (0) an invitation and the methodological clarification of the study to the participants. After 2 weeks, analysis of body composition and flexibility, electrocardiography (ECG)-based examination at rest, and an ergospirometric test were performed in conjunction with exercise ECG. Blood collections for biochemical evaluation were started after 4 weeks.

\section{Participants}

The 16 referees who participated in this study are linked to the Espírito Santo Football Federation (FES) and make up the CBF board. The sample consisted of 6 main referees and 10 assistant referees. The Informed Consent Form was distributed and signed by the participants, after they became aware of the study methods, procedures, and risks. This study was approved by the Research Ethics Committee Involving Human Beings of the Federal University of Espírito Santo under number 584002816.7.0000.5542. 


\section{Body composition}

Body composition analysis was performed using the following body parameters: height (measured using a stadiometer; CESCORF), body mass (measured using a digital balance with 0.1-kg precision; Bioland), body mass index (BMI), and body fat percentage (measured using a Lange ${ }^{\circledR}$ scientific adipometer with $0.1-\mathrm{mm}$ variation). The classification of BMI and adiposity levels was in accordance with the recommendations of the World Health Organization.

\section{Flexibility}

Flexibility was analyzed using the sit and reach test, following the standardization and classification of physical fitness assessment tests of the Canadian Standardized Test of Fitness ${ }^{17}$ (Table 1).

\section{Cardiorespiratory profile}

Cardiorespiratory fitness assessment was performed using resting ECG and cardiopulmonary exercise testing. Initially, the referees were kept in dorsal decubitus position for at least $5 \mathrm{~min}$. Then, resting ECG (MICROMED, Brasília, Brazil) was performed using 12 conventional leads in order to detect any arrhythmia, conduction disorders, myocardial ischemia, or acute myocardial infarction. The electrocardiographic recordings during pre-stress, while standing on the treadmill, and during exertion were performed using the simultaneous leads MC5, D2M, and V2M. The test was performed on a motorized treadmill (Inbra Sport Super ATL, Porto Alegre, Brazil) kept at a $1 \%$ slope, following an individual ramp protocol with incrementally increased speed until the subject reached exhaustion. The test was started with a speed of $6 \mathrm{~km} / \mathrm{h}$, with an increase of speed of $1 \mathrm{~km} / \mathrm{h}$ every minute.

Measurement of ventilatory variables was performed using a metabolic gas analyzer (CortexMetalyzer 3B, Leipzig, Germany), with the $\mathrm{VO}_{2}$ max, from the breath-to-breath collection, analyzed using the Metasoft ${ }^{\circledR}$ program. To identify the test as having reached the maximum level, at least 3 of the following criteria should be met: a) voluntary exhaustion, b) at least $90 \%$ of the age-predicted maximum HR $(208-[0.7 \times$ age $\left.]){ }^{18} \mathrm{C}\right)$ respiratory exchange ratio $\geq 1.05$, and d) maximum oxygen consumption based on the concept of plateau or peak.

\section{Biochemical profile}

After a minimum of $12 \mathrm{~h}$ of fasting, blood samples $(\cong 10 \mathrm{~mL}$ in EDTA) were collected via vacuum venipuncture (Vacutainer ${ }^{\circledR}$, England), centrifuged at $3000 \times g$ for 10 min (ThermoScientific, USA), and then stored in microtubes at $-80^{\circ} \mathrm{C}$ (Coldlab, Brazil). The serum concentrations of glucose, total cholesterol, triglycerides, and high-density lipoprotein were determined using specific kits (Bioclin ${ }^{\circledR}$, Brazil) and analyzed with the BS-200 equipment (Mindray do Brasil, Brazil).

\section{Statistical analysis}

Sample size calculation, tabulation, and data analysis were performed using SigmaStat 3.5 and Microsoft Excel 2010. Data were expressed as

Table 1. Sit and reach test ratings.

\begin{tabular}{c|c|c|c|c|c|c}
\hline \multicolumn{7}{c}{ Sit and reach - men - with a bench $(\mathbf{c m})$} \\
\hline Age (years) & $15-19$ & $20-29$ & $30-39$ & $40-49$ & $50-59$ & $60-69$ \\
\hline Excellent & $>39$ & $>40$ & $>38$ & $>35$ & $>35$ & $>33$ \\
\hline Above average & $34-38$ & $34-39$ & $33-37$ & $29-34$ & $28-34$ & $25-32$ \\
\hline Average & $29-33$ & $30-33$ & $28-32$ & $24-28$ & $24-27$ & $20-24$ \\
\hline Below average & $24-28$ & $25-29$ & $23-27$ & $18-23$ & $16-23$ & $15-19$ \\
\hline Poor & $<23$ & $<24$ & $<22$ & $<17$ & $<15$ & $<14$ \\
\hline \multicolumn{7}{|c|}{ Sit and reach - women - with a bench (cm) } \\
\hline Age (years) & $15-19$ & $20-29$ & $30-39$ & $40-49$ & $50-59$ & $60-69$ \\
\hline Excellent & $>43$ & $>41$ & $>41$ & $>38$ & $>39$ & $>35$ \\
\hline Above average & $38-42$ & $37-40$ & $36-40$ & $34-37$ & $33-28$ & $31-34$ \\
\hline Average & $34-37$ & $33-36$ & $32-35$ & $30-33$ & $30-32$ & $27-30$ \\
\hline Below average & $29-33$ & $28-32$ & $27-31$ & $25-29$ & $25-29$ & $23-26$ \\
\hline Poor & $<28$ & $<27$ & $<26$ & $<24$ & $<24$ & $<22$ \\
\hline
\end{tabular}

mean \pm standard deviation and submitted to the Kolmogorov-Smirnov test to determine adherence to normality. The correlation analysis between body composition and aerobic capacity was performed using Pearson correlation coefficients. The significance level was set at 5\%.

\section{RESULTS}

The sample consisted of 16 referees, $87.5 \%$ men and 12.5\% women (data not shown). The referees had a mean age, body mass, and height of $34.2 \pm 4.07$ years, $79.8 \pm 11.9 \mathrm{~kg}$, and $1.78 \pm 0.08 \mathrm{~m}$, respectively (Table 2 ). The participants were divided into the following age group categories: between 20 and 30 years (12.5\%), between 30 and 40 years (81.25\%), and $>40$ years $(6.25 \%)$ (data not shown).

The results showed that the referees were classified in the "overweight" category (BMl: $25.2 \pm 2.50 \mathrm{~kg} / \mathrm{m}^{2}$ ) but were not characterized as in a pre-obese state, because they presented satisfactory levels of body fat percentage (15.6 $\pm 3.51 \%)$ and a low risk for the development of metabolic syndrome and comorbidities. In addition, they presented satisfactory values of lean mass $(67.2 \pm 9.40 \mathrm{~kg})$ and fat mass $(12.6 \pm 3.50 \mathrm{~kg})$ (Table 3). Moreover, the referees presented average biochemical values within the normal limits.

On the basis of the BMI assessment, $56 \%$ of the referees were classified as eutrophic and $44 \%$ as overweight (Figure $1 \mathrm{~A}$ ). The waist-to-hip ratio data showed that $81 \%$ of the referees presented no risk for the development of metabolic syndrome and associated comorbidities, whereas 19\% were at a risk for developing cardiovascular disease (Figure 1B). All study participants had satisfactory fat percentage values (Figure 1C).

In terms of flexibility, most of the referees were determined to need improvement (25\%) or to have fair flexibility (25\%), whereas 31\%, $6 \%$, and $13 \%$ of the participants presented average, good, and excellent flexibility, respectively (Table 4).

With respect to the test time, distance covered, and exhaust velocity, the mean values were $10.2 \pm 1.10 \mathrm{~min}, 1.91 \pm 0.37 \mathrm{~km}$, and $16.2 \pm 1.40$ $\mathrm{km} / \mathrm{h}$, respectively (Table 5 ). The resting, reserve, and maximum HR values were $64 \pm 13,120 \pm 12$, and $184 \pm 3 \mathrm{bpm}$, respectively. The mean $\mathrm{VO}_{2}$ max was $45.3 \pm 5.67 \mathrm{ml} \cdot \mathrm{kg}^{-1} \cdot \mathrm{min}^{-1}$.

In terms of the cardiorespiratory condition, $50 \%, 37.5 \%$, and $12.5 \%$ of the referees were graded as good, excellent, and fair according to the American Heart Association criteria (Figure 2).

The results showed that there was a moderate and significant negative correlation between the levels of $\mathrm{VO}_{2}$ max and body fat percentage (\%) (Table 6).

Table 2. General characteristics.

\begin{tabular}{c|c|c|c}
\hline Variables & Mean \pm SD & Minimum & Maximum \\
\hline Age (years) & $34.2 \pm 4.07$ & 26.0 & 41.0 \\
\hline Body mass $(\mathrm{kg})$ & $79.8 \pm 11.9$ & 56.1 & 98.6 \\
\hline Height $(\mathrm{m})$ & $1.78 \pm 0.08$ & 1.65 & 1.92 \\
\hline SD, standard deviation.
\end{tabular}

Table 3. Body composition and biochemical profile.

\begin{tabular}{|c|c|c|c|}
\hline Variables & Mean \pm SD & Minimum & Maximum \\
\hline BMI $\left(\mathrm{kg} / \mathrm{m}^{2}\right)$ & $25.2 \pm 2.50$ & 20.6 & 29.6 \\
\hline Body fat percentage & $15.6 \pm 3.51$ & 9.24 & 21.7 \\
\hline Lean mass $(\mathrm{kg})$ & $67.2 \pm 9.40$ & 44.8 & 81.0 \\
\hline Fat mass (kg) & $12.6 \pm 3.50$ & 6.79 & 21.4 \\
\hline Waist-to-hip ratio & $0.83 \pm 0.08$ & 0.65 & 0.95 \\
\hline Glucose (mg/dL) & $88.7 \pm 8.20$ & 76.0 & 105 \\
\hline $\mathrm{TG}(\mathrm{mg} / \mathrm{dL})^{\#}$ & $76.8(63.6 ; 124)$ & 49.5 & 437 \\
\hline Cholesterol (mg/dL) & $200 \pm 36.0$ & 155 & 266 \\
\hline $\mathrm{HDL}(\mathrm{mg} / \mathrm{dL})$ & $60.8 \pm 18.6$ & 37.0 & 112 \\
\hline
\end{tabular}

Participants $(n=16)$. SD, standard deviation; $\mathrm{BMI}$, body mass index; $\mathrm{TG}$, triglycerides; $\mathrm{HDL}$, high-density lipoprotein \#Values are presented as median (25th percentile; 75 th percentile). 


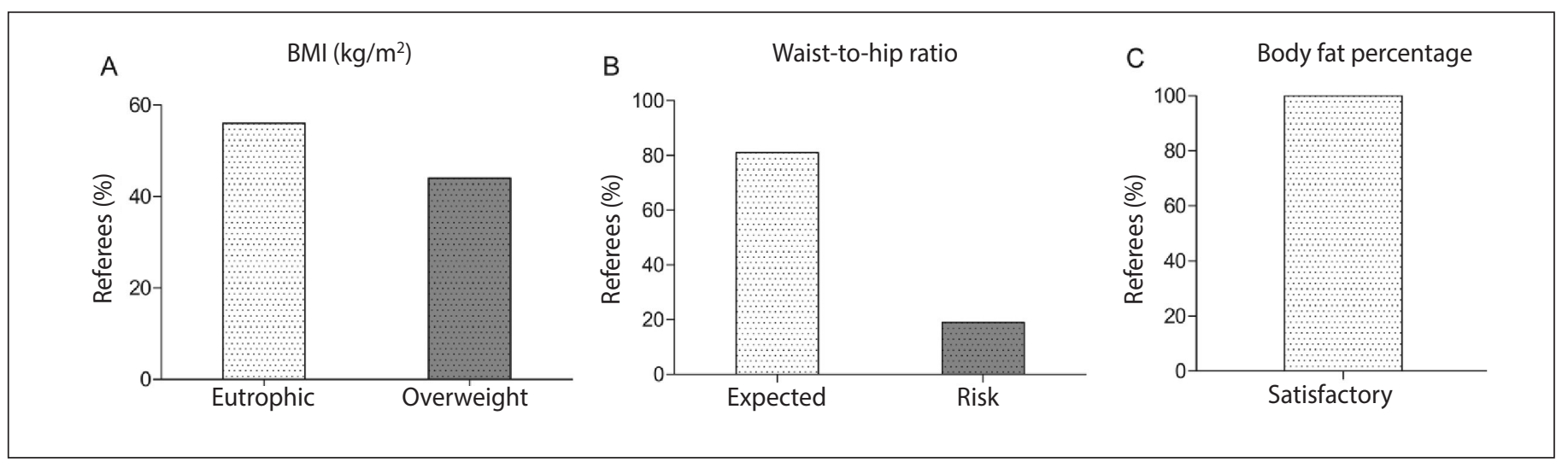

Figure 1. Classification of referees in terms of body composition. A) Body mass index (BMl): eutrophic, $<24.9 \mathrm{~kg} / \mathrm{m}^{2}$; overweight, between $25 \mathrm{and} 29.9 \mathrm{~kg} / \mathrm{m}^{2} ;$ obese, $>30 \mathrm{~kg} / \mathrm{m}^{2}$. B) Expected waist-to-hip ratio: women $<0.85$ and men $<0.90$. C) Body fat percentage considered satisfactory for good health: women $20-32 \%$ and men 10 .

Table 4. Flexibility.

\begin{tabular}{c|c|c}
\hline & Absolute frequency (n) & Relative frequency (\%) \\
\hline Needs improvement & 4 & $25 \%$ \\
\hline Fair & 4 & $25 \%$ \\
\hline Average & 5 & $31 \%$ \\
\hline Good & 1 & $6 \%$ \\
\hline Excellent & 3 & $13 \%$ \\
\hline
\end{tabular}

Table 5. Cardiorespiratory fitness.

\begin{tabular}{c|c|c|c}
\hline Variables & Mean \pm SD & Minimum & Maximum \\
\hline Test time $(\mathrm{min})$ & $10.2 \pm 1.10$ & 7.05 & 12.1 \\
\hline Distance covered $(\mathrm{km})$ & $1.91 \pm 0.37$ & 1.11 & 2.41 \\
\hline Exhaust velocity $(\mathrm{km} / \mathrm{h})$ & $16.2 \pm 1.40$ & 13.0 & 18.0 \\
\hline Resting HR $(\mathrm{bpm})$ & $64.0 \pm 13.0$ & 42.0 & 89.0 \\
\hline Reserve HR $(\mathrm{bpm})$ & $120 \pm 12$ & 97.3 & 144.3 \\
\hline Maximum HR $(\mathrm{bpm})$ & $184 \pm 3$ & 179 & 190 \\
\hline $\mathrm{VO}_{2}$ max $\left(\mathrm{ml} \cdot \mathrm{kg}^{-1} \cdot \mathrm{min}^{-1}\right)$ & $45.3 \pm 5.67$ & 35.4 & 55.7 \\
\hline
\end{tabular}

$\mathrm{SD}$, standard deviation; $\mathrm{HR}$, heart rate; $\mathrm{VO}_{2} \mathrm{max}$, maximum oxygen consumption; bpm, beats per minute.

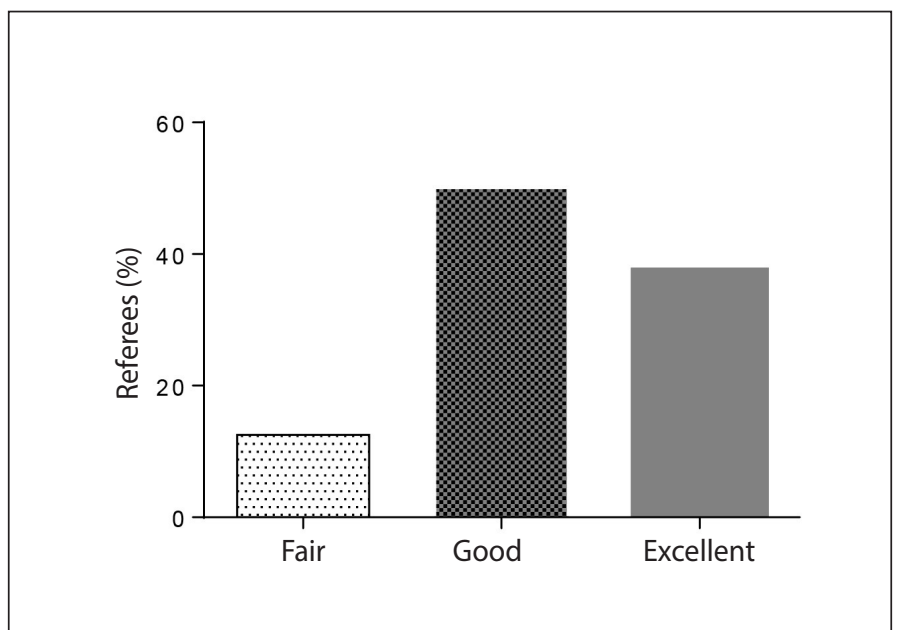

Figure 2. Percentage distribution of the cardiorespiratory fitness of the capixabas referees linked to the CBF (Brazilian Football Confederation) national board.

Table 6. Correlation between $\mathrm{VO}_{2}$ max and anthropometric parameters.

\begin{tabular}{c|c|c}
\hline & \multicolumn{2}{|c}{$\mathbf{V O}_{2} \mathbf{m a x}\left(\mathbf{m l} \cdot \mathrm{kg}^{-1} \cdot \mathbf{m i n}^{-1}\right)$} \\
\hline Variables & $r$ & $p$ \\
\hline BMl & -0.20 & 0.456 \\
\hline Fat $\%$ & -0.54 & 0.031 \\
\hline
\end{tabular}

$\mathrm{VO}_{2}$ max, maximum oxygen consumption; r, correlation coefficient; BMl, body mass index. Pearson correlation analysis, $\mathrm{p}<0.05$.

\section{DISCUSSION}

Soccer referees linked to Federations located in regions with weaker leagues and teams of lower tier or level need to maintain suitable physical, technical, and psychological conditions to be eligible to work in national and international competitions, should they be invited into the CBF and FIFA boards, respectively. In the literature, it is well established that the physical condition of the referees has a large influence on their technical performance during matches. ${ }^{3}$ In addition, few studies have addressed the health of these professionals, who are less attended by the regulators of the sport., 2,12,15,16 The main findings of the present study emphasize that, even when working in leagues of lower tiers or levels and with fewer working conditions, the FES capixabas referees present a low risk for the development of chronic diseases, as well as a good body structure and physical fitness to work in regional, national, or international matches.

Physical capacity is inversely proportional to age..$^{19}$ Thus in the context of soccer, this relationship may ${ }^{2}$ or may not have a negative influence on the technical/tactical performance of referees. ${ }^{20}$ Studies have suggested that a slight impairment in physical fitness due to age can be overcome by relevant experience in refereeing, and consequently, does not affect the technical performance of these professionals. ${ }^{13}$ Importantly, to ensure the good physical and technical performance of referees, each league sets an age limit for these professionals, with the FIFA and CBF having recently considered 50 years as the maximum age. Within this context, all referees present age range set by the governing bodies in soccer (i.e., 26-41 years), to work in leagues at the regional, national, and international levels.

Another key component for the optimization of both the performance and health of soccer referees is body composition control.2,21 When the level of physical conditioning is low, changes in parameters such as body mass, BMI, fat percentage, and waist-to-hip ratio occur. These changes are strongly related to the development of metabolic syndrome and cardiovascular diseases. With respect to soccer referees, previous studies have suggested that body composition imbalance has negative effects on the physical and technical conditions, ${ }^{2,21}$ which can directly influence the quality of refereeing during matches. In this context, most participants of the present study presented a low risk for metabolic and cardiovascular diseases, as confirmed by their satisfactory levels of fat percentage and BMI. In addition, fat percentage showed a negative correlation with $\mathrm{VO}_{2}$ max, which reinforces that body composition control is related to better aerobic fitness. Moreover, the body composition evaluation also showed that the capixabas referees presented excellent health levels when compared with the general population, and showed a physical structure similar to that of referees of large centers. ${ }^{21,22}$ 
The biochemical tests showed that the glycemic and lipid profiles of the capixabas referees presented values within the normal limits. However, when analyzed individually, the results showed that 1 referee had increased glucose, 3 had high triglycerides, and 6 had changes in total cholesterol, representing $63 \%$ of the sample with some alterations in the analyzed parameters. In the individual context, some referees presented negative changes that are generally associated with the development of metabolic syndrome, ${ }^{23}$ which may indicate the need for greater control and for studies on the training and dietary profile of these professionals.

Previous studies have shown that soccer referees present poor levels of flexibility, which could lead to injuries and poor sport performance. ${ }^{24,25}$ Good flexibility might allow referees to move at optimal speeds with a greater range of motion and displacement during a match, thus minimizing physical and energetic wear and tear, and positively influencing their decision-making skills. It is noteworthy that, in disagreement with the aforementioned studies, $75 \%$ of the participants presented an fair to excellent performance in the flexibility test, which can be advantageous for physical performance and can minimize the risk of injury.

Finally, soccer referees generally have a good athletic condition characterized by excellent levels of cardiorespiratory fitness, such as resting bradycardia. ${ }^{2-4,12,26}$ In agreement with previous studies, resting ECG demonstrated this characteristic in the referees of the present study. ${ }^{27,28}$ In the evaluation during effort, the sample showed satisfactory values of reserve $H R$ and increase of resting $H R$ to $H R$ at the point of maximum effort, considered an important predictor of cardiovascular diseases and sudden death. ${ }^{29}$ In addition, all the capixabas referees were classified into the fair (10\%), good (50\%), and excellent (40\%) categories. Corroborating with our data, other authors reported moderate values of $\mathrm{VO}_{2}$ max, ranging from 44 to $56 \mathrm{ml}^{\circ} \mathrm{kg}^{-1} \cdot \mathrm{min}^{-1}$. 1,3,4,27,30 This result can be explained by the fact that referees do not need to significantly increase their $\mathrm{VO}_{2}$ max during matches to obtain better performance, reaching the maximum value of $50 \mathrm{ml} \cdot \mathrm{kg}^{-1} \cdot \mathrm{min}^{-1}$ in $90 \mathrm{~min}{ }^{1}$ Thus, the capixabas referees presented good physical fitness related to health and physical performance, which makes them eligible to work in different leagues and/or championships.

\section{CONCLUSION}

The capixabas referees, who make up the CBF national board, presented satisfactory health levels indicated by their good body composition and low risk for the development of chronic diseases, as well as sufficient cardiorespiratory fitness to work in regional, national, or international matches.

\section{ACKNOWLEDGMENTS}

The authors thank the Espírito Santo Football Federation (FES) and the Brazilian Football Confederation (CBF) for their support of this study.

All authors declare no potential conflict of interest related to this article

AUTHORS' CONTRIBUTIONS: Each author contributed individually and significantly to the development of the manuscript. VLS (0000-0001-7796-6215)* acquired and analyzed the data, and drafted and critically revised the manuscript. CERD (0000-0001-8470-941X)* designed and carried out the study, and acquired, analyzed, and interpreted the data. LC (0000-0003-0085-1705)* analyzed and interpreted the cardiorespiratory data, and drafted and critically reviewed the intellectual content of the manuscript. RLV (0000-0003-1981-1092)* analyzed and interpreted the data, and wrote the final version and critically reviewed the manuscript. APLL (0000-0002-4049-4418)* conceptualized and designed the study, analyzed the biochemical data, and drafted and critically reviewed the intellectual content of the manuscript. ASL (0000-0002$3131-2467)^{*}$ conceptualized the study, analyzed and interpreted the data, conducted the statistical analysis, and drafted and critically reviewed the intellectual content of the manuscript. All authors approve the final version of the manuscript. *ORCID (Open Researcher and Contributor ID).

\section{REFERENCES}

1. Castagna C, Abt G, D'Ottavio S. Physiological aspects of soccer refereeing performance and training. Sports Med. 2007;37(7):625-46.

2. Da Silva Al, Nascimento AJ. Composição corporal e aptidão física de árbitros da CBF submetidos à nova ordem de aplicação dos testes físicos da FIFA. Fitness Performance J. 2005;4(5):306-12.

3. Vieira CMA, Costa EC, Aoki MS. O nível de aptidão física afeta o desempenho do árbitro de futebol? Rev bras Educ Fís. 2010;24(4):445-52.

4. Ishihara Y, Naito H, Ozaki H, Yoshimura M. Aerobic fitness relation to mach performance of Japanese soccer referees. Football Sci. 2015;12:91-7.

5. Da Silva Al, Rodriguez-Añez CR. Dispêndio energético do árbitro de do árbitro assistente de futebol. Rev Educ Fís. 2001;12(2):113-8.

6. Weston M, Castagna C, Impellizzeri FM, Bizzini M, Williams AM, Gregson W. Science and medicine applied to soccer refereeing: an update. Sports Med. 2012;42(7):615-31.

7. Castillo D, Weston M, McLaren SJ, Camara J, Yanci J. Relationships between Internal and External Match Load Indicators in Soccer Match Officials. Int J Sports Physiol Perform. 2017;12(7):922-7.

8. Schenk K, Bizzini M, Gatterer H. Exercise physiology and nutritional perspectives of elite soccer refereeing. Scand J Med Sci Sports. 2018;28(3):782-93.

9. D'Ottavio S, Castagna C. Physiological load imposed on elite soccer referees during actual match play. J Sports Med Phys Fitness. 2001;41(1):27-32

10. Krustrup P, Bangsbo J. Physiological demands of top-class soccer refereeing in relation to physical capacity: effect of intense intermittent exercise training. J Sports Sci. 2001;19(11):881-91.

11. Krustrup P, Mohr M, Bangsbo J. Activity profile and physiological demands of top-class soccer assistant refereeing in relation to training status. J Sports Sci. 2002;20(11):861-71.

12. Da Silva Al, Fernandez R, Fernandes LC. Índice de massa corporal e perímetro da cintura de árbitros de futebol da CBF. Rev Educ Fís. 2007;18(1):41-7.

13. Mazaheri R, Halabchi F, Barghi TS, Mansournia MA. Cardiorespiratory Fitness and Body Composition of Soccer Referees. Do These Correlate With Proper Performance? Asian J Sports Med. 2016;7(1):1-5.

14. Castagna C, D'Ottavio S. Effect of maximal aerobic power on match performance in elite soccer referees. J Strength Cond Res. 2001;15(4):420-5.

15. Da Silva Al, Dourado AC, Durigan JZ. Perfil morfológico dos árbitros assistentes de elite do futebol. Rev Bras Futebol. 2013;6(1):76-84.

16. Da Silva A. O IMC e o perímetro da cintura como indicadores de risco para a saúde de árbitros de futebol do brasil. Fitness Perf J. 2006;5(4):223-31

17. Canadian Standardized Test of Fitness (CSTF) Operations Manual, 3rd ed, Fitness and Amateur Sport. Ottawa: Minister of State; 1986.

18. Tanaka H, Monahan KD, Seals DR. Age-predicted maximal heart rate revisited. J Am Coll Cardiol. 2001;37(1):153-6.

19. Suominem H. Ageing and maximal physical performance. Eur Rev Aging Phys Perf. 2011;8(1):37-42.

20. Weston M, Castagna C, Impellizzeri FM, Rampinini E, Breivik S. Ageing and physical match performance in English Premier League soccer referees. J Sci Med Sport. 2010;13(1):96-100.

21. Casajús JA, Matute-Llorente A, Herrero H, González-Aguero A. Body Composition in Spanish Soccer Referees. Meas Control. 2014;47(6):178-84.

22. Casajús JA, Matute-Llorente A, Herrero AH, Vicente-Rodríguez G, González-Aguero A. Body fat in elite Spanish football referees and assistants: A 1-year follow-up study. Apunts Med l'Esport. 2016;51(189):21-6.

23. Rochlani Y, Pothineni NV, Kovelamudi S, Mehta JL. Metabolic syndrome: pathophysiology, management, and modulation by natural compounds. Ther Adv Cardiovasc Dis. 2017;11(8):215-25.

24. Silva ML, Da Silva Al. Perfil antropométrico e capacidade física dos alunos da escola de árbitro de futebol do Ceará. Rev Bras Presc Fis Exerc. 2012;6(32):98-107.

25. De Oliveira MC, Da Silva AI, Paes MR. Incidência de lesão musculoesquelética em árbitros de futebol de São Paulo. Rev Carioca Educ Fís. 2015;(10):115-22.

26. Almeida MB, Araújo CGS. Effects of aerobic training on heart rate. Rev Bras Med Esporte. 2003;9(2):113-20.

27. Gianturco L, Bodini BD, Gianturco V, Lippo G, Solbiatti A, Turiel M. Left ventricular longitudinal strain in soccer referees. Oncotarget. 2017;8(24):39766-73.

28. Ruiz Caballero JA, Britto Ojeda E, García-Aranda JM, Mallo J, Helsen W, Sarmiento S, et al. Echocardiographic study of structure and functional cardiac profile of football referees. J Sports Med Phys Fitness. 2011;51(4):633-8

29. Engeseth K, Hodnesdal C, Grundvold I, Liestol K, Gjesdal K, Erikssen G, et al. Heart rate reserve predicts cardiovascular death among physically unfit but otherwise healthy middle-aged men: a 35-year follow-up study. Eur J Prev Cardiol. 2016;23(1):59-66.

30. Castagna C, Bizzini M, Araújo Póvoas SC, Schenk K, Büsser G, D'Ottavio S. Aerobic Fitness in Top-Class Soccer Referees. J Strength Cond Res. 2017. 